\title{
Model of Scientific and Methodological Support for Training of Mentors for Vocational Education System in the Conditions of Digitalization
}

\author{
Almaz Gapsalamov ${ }^{1}$, Elvir Akhmetshin ${ }^{1 *}$, Irek Falyakhov ${ }^{1}$, Vladimir Vasilev ${ }^{1}$, Sergei Sedov ${ }^{1}$ \\ ${ }^{1}$ Kazan Federal University, Elabuga Institute of KFU, Elabuga, Russia
}

\begin{abstract}
Under the influence of digitalization, pedagogical activity in the system of modern vocational education is complicated and requires the mastering and improvement of competences in the field of design and the creation of a practicaloriented environment for training. Mentoring in such a system is becoming a key element in the training of competitive personnel. In this regard, it is fair to speak of the relevance of teacher training on the basis of the principles of variability and modularity, with the possibility of providing different entry paths, taking into account the availability or lack of experience in pedagogical activities, as well as basic profession and individual needs. The study is based on the use of methods of theoretical analysis, systematization, generalization of scientific and pedagogical literature on the topic of research, modeling. In the course of the study, the significance of the mentor's psychological and pedagogical competence for vocational education system was shown, the content of its motivational-value, cognitive, process-activity, and reflective-analytical components that determine the effectiveness of the implementation of productive mentoring in the context of digitalization. A structural model of scientific and methodological support for the training of mentors for vocational education system in the context of digitalization is proposed.
\end{abstract}

Keywords: digitalization, professional education, mentor, scientific and methodological support, model

\section{Introduction}

Studying the works of teachers, practitioners, producers concerning the modernization of vocational education [1-5] it is possible to summarize systemic problems of professional education, there are: unmanageable impact of digitalization on the quality of personnel training; dynamics of stakeholders "requirements to the quality of education as a dynamic indicator, the criteria of which also change as the social order is renewed to the university in conditions of digitalization, against the background of trends of globalization, informatization, etc.; low professionalism of training activities; the difficulty of integrating educational and professional standards and the need to focus them ahead; insufficient format of interaction between education and production; lack of scientific and methodological support for vocational training in vocational education organizations, which leads to scientific, organizational, psychological and pedagogical functions of education [6-9].

Strategic documents adopted by the Government: a set of measures aimed at improving the vocational education system; plan of measures to ensure productivity improvement, creation and modernization of high-productivity jobs; the plan of measures aimed at popularizing workers and engineering professions, developed on the basis of the results of the project "Training of workers meeting the requirements of high-tech industries on the basis of dual education," emphasizes the importance of practical-oriented forms of training and defines a number of measures to motivate enterprises when they are included in the practical-oriented model of training. To date, many regional enterprises involved in the project continue to develop structured mechanisms, the characteristic feature of which is interaction between the Government, enterprises, trade unions

\footnotetext{
*Corresponding author: elvir@mail.ru
} 
and educational organizations, the latter of which perform a supporting, cultural, developing and organizational-accompanying role, leaving the priority of training to enterprises [10-13].

One aspect of the implementation of the practical-oriented model of vocational education is the introduction of a mentoring system, which is in no way an innovative mechanism, and has a centuries-old history, ensuring entry into the craft, profession [14], but definitely requires rethinking in the context of digitalization. In our study we rely on the definition of A.R. Masalimova, representing mentoring "as a social, pedagogical, economic and production phenomenon in the conditions of modern enterprises, a form of corporate training of young specialists, contributing to the maintenance of inter-firm competition, viability, status, stability of enterprises and preservation of their information confidentiality" [15].

\section{Literature review}

Analysis of scientific and pedagogical literature shows that in studies of the Soviet period:

- psycho-pedagogical basis of mentoring as a pedagogical system developed [16-19]:

- peculiarities of mentoring system organization as a form of industrial training are identified [20-22];

- social-psychological [23-24] historical [25] aspects of formation and development of the institute of mentoring are revealed.

In research of the modern period:

- traditions of mentoring in the history of domestic education are revealed [26];

- mechanisms and conditions for the formation of vocational and pedagogical competence of mentors have been developed [27-29];

- the psychological content of mentoring is justified [30-31];

- theoretical, methodological and methodological bases of corporate training and advanced training of enterprise personnel have been developed [15, 32-35].

In foreign research, the foundations of mentoring are revealed in works by H. G. Bauer (2010) [36], M. J. Boca [37], J. Homburg [38], J. Niedermair [39].

At the same time, the problem of training mentors for the vocational education system in modern conditions, the issue of scientific and methodological support of this process in the conditions of digitalization, has not been sufficiently studied.

\section{The experimental part}

As part of our study, we consider it appropriate to highlight four main functions of the mentor:

- a professionally-oriented function that determines the formation of professional competencies and production experience of the trainee, corresponding to his future qualifications;

- motivational-value function, which involves the formation of meaningful positive motives from interns to the chosen professional activity, their inclusion into corporate values and traditions of the enterprise, the formation of their corporate culture;

- management and consulting function, involving the organization and management of training of interns, including in the framework of joint consultations with teachers;

- methodological function, which consists in the development, adaptation, implementation of effective educational and educative technologies for training trainees.

Based on the functions of a modern mentor that we highlighted for the vocational education system, in addition to high-quality professional training, the presence of a corporate culture, leadership qualities, personal maturity and responsibility, the need for psychological and pedagogical training is obvious. The result of this training will be the formation of a special psychological and pedagogical competence of the mentor, as a combination of his knowledge, abilities and readiness for the implementation of pedagogical activity, providing high-quality results and effective professional interaction with students in digitalization.

The structure of psychological and pedagogical competence of the mentor, in our opinion, includes a set of the following components:

- motivational and value component, which ensures, based on the system of interests and motives of the mentor, his vocational and pedagogical behavior, focus on the design and implementation of the educational process in the framework of corporate culture;

- the cognitive component due to methodological, managerial, psychological, pedagogical and professional knowledge of the essence of vocational training and its technologies;

- procedural and activity component, which involves ownership of methods of organization of training of trainees considering individual peculiarities of trainees, opportunities of individual and group training, creation of educational communications and environment for professional development of trainees; 
- reflective and analytical, characterized by the ability to holistic vision and analysis of the results of their own mentoring activities, providing the basis for self-improvement, selfdevelopment and self-realization.

\section{Results and Discussion}

For realization of a system of training of mentors it is developed on the basis of an algorithm of pedagogical modeling of A.N. Dakhin [40] structural model of scientific and methodical ensuring training of mentors for the system of professional education in the conditions of digitalization. By scientific and methodological support, we mean a set of methodological and didactic developments that meet the modern requirements of pedagogical science and practice. Two levels of it were highlighted: scientific-theoretical and scientific-practical (Table 1).

Table 1. Structural model of scientific and methodological support for training of mentors for vocational education system.

\begin{tabular}{|c|c|c|c|c|c|c|}
\hline \multirow{4}{*}{ 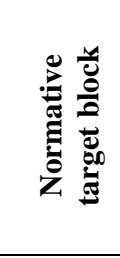 } & \multirow{2}{*}{\multicolumn{2}{|c|}{ Normative base }} & \multirow{2}{*}{$\leftrightarrow$} & \multicolumn{2}{|c|}{ Social order } & \\
\hline & & & & & $\downarrow$ & \\
\hline & \multicolumn{5}{|c|}{$\begin{array}{l}\text { Purpose: formation of psychological and pedagogical competence of mentors for } \\
\text { vocational education system. }\end{array}$} & \\
\hline & \multicolumn{5}{|c|}{$\begin{array}{l}\text { Tasks: formation of a motivational and valuable component; formation of a cognitive } \\
\text { component; formation of a procedural and activity component; formation of a reflexive } \\
\text { and analytical component. }\end{array}$} & \\
\hline & & & $\downarrow$ & & & \\
\hline 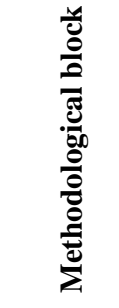 & \multicolumn{2}{|c|}{$\begin{array}{l}\text { Methodological } \\
\text { approaches: } \\
\text { andragogical; } \\
\text { integrative; } \\
\text { modular and competence- } \\
\text { based. }\end{array}$} & $\leftrightarrow$ & \multicolumn{2}{|c|}{$\begin{array}{l}\text { Methodological principles: } \\
\text { targeted orientation, development, social } \\
\text { partnership, integration of vocational } \\
\text { and pedagogical activities, information } \\
\text { value }\end{array}$} & t? \\
\hline \multicolumn{6}{|c|}{ e } & \\
\hline \multirow{6}{*}{ 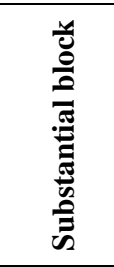 } & \multicolumn{2}{|c|}{$\begin{array}{l}\text { Theory of adult education, } \\
\text { andragogics, acmeology }\end{array}$} & & \multicolumn{2}{|c|}{$\begin{array}{l}\text { Strategic objectives of the enterprise, } \\
\text { prof. standards, corporate culture }\end{array}$} & \\
\hline & \multirow{2}{*}{\multicolumn{2}{|c|}{$\downarrow$}} & & & $\downarrow$ & \\
\hline & \multicolumn{4}{|c|}{ selection of components of psychological and pedagogical competence of mentors } & & \\
\hline & \multicolumn{5}{|c|}{ design mentor training content } & \\
\hline & \multirow{2}{*}{\multicolumn{5}{|c|}{$\begin{array}{l}\text { development of a mentor training program } \\
\text { development of mentor training modules }\end{array}$}} & \\
\hline & & & & & & \\
\hline \multirow{5}{*}{ 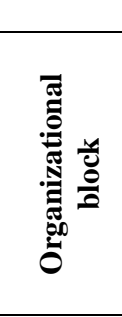 } & \multicolumn{5}{|c|}{ development of mentor training modules } & \\
\hline & \multirow{4}{*}{ 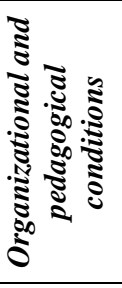 } & \multicolumn{4}{|c|}{$\begin{array}{l}\text { 1. development of training and methodical support for the training } \\
\text { mentors }\end{array}$} & \\
\hline & & \multicolumn{4}{|c|}{ 2. development of an organizational structure for the training of mentors } & \\
\hline & & 3. psychologica & dagog & upport for th & ining of mentors & \\
\hline & & \multicolumn{4}{|c|}{ 4. development of diagnostic tools for the training of mentors } & \\
\hline \multicolumn{6}{|c|}{$\downarrow$} & \\
\hline \multirow{4}{*}{ 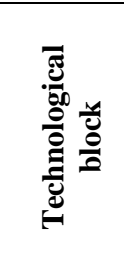 } & \multicolumn{5}{|c|}{ Implementation of mentor training modules } & 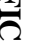 \\
\hline & \multicolumn{5}{|c|}{$\begin{array}{c}\text { Forms: -individual, group, frontal Lectures, seminars, independent work } \\
\text { - lectures, seminars, independent work }\end{array}$} & 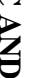 \\
\hline & \multicolumn{5}{|c|}{$\begin{array}{c}\text { Technologies: ICT, modular learning, problem learning; } \\
\text { remote technologies of training }\end{array}$} & 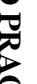 \\
\hline & \multicolumn{5}{|c|}{ Methods: traditional, active (imitation and non-imitation) } & \\
\hline \multirow{7}{*}{ 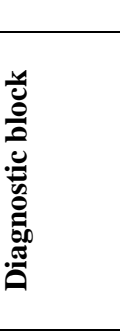 } & & & & & & \\
\hline & & & & ance contro & & \\
\hline & . & $\begin{array}{l}\text { There is n } \\
\text { experience } \\
\text { mentoring }\end{array}$ & & $\begin{array}{l}\text { perience of } \\
\text { toring }\end{array}$ & $\begin{array}{l}\text { There is an experience } \\
\text { of mentoring }\end{array}$ & \\
\hline & 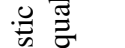 & & & king of stu & & \\
\hline & $\stackrel{0}{0}$ & & & ntrol of stuc & & \\
\hline & .్తి & & sych & and pedago & I competence & \\
\hline & & admissib & & iverage & high & \\
\hline & & & $\downarrow$ & & & \\
\hline & & RESULT: INT & POI & QUALIFI & ION & \\
\hline
\end{tabular}




\begin{tabular}{|l|l|l|l} 
MENTOR & TUTOR & COACH & FACILITATOR \\
\hline
\end{tabular}

Scientific-theoretical level includes: targeting, theoretical bases, concepts, principles and design of the content of training mentors for vocational education system.

Scientific and practical level Involves development of organizational and pedagogical conditions, selection of technologies and diagnostic tools for training mentors.

The peculiarities of scientific and methodological support of training of mentors are: implementation of pedagogical training within the framework of internal training; The need for mentors to participate in the development and education of learners; Personal orientation and personal significance of the result of the education of mentors for the student and employer, which determine the competitiveness of each of them in the labor market.

The developed structural model consists of six interconnected blocks:

Regulatory and objective, ensuring, based on the requirements of the employer and social order, the targeting of the training of mentors for vocational education;

methodological, forming the orientation of scientific and methodological support for the training of mentors and its logical structure on the basis of a set of approaches (andragogic, integrative, modular-competent) and principles (targeted orientation, development, social partnership, integration of vocational and pedagogical activities, informativity);

- informative, defining the content of the process of the formation of psychological and pedagogical competence as the core of the training of mentors, forming an integrated training system from setting goals to achieving results;

- organizational, including a set of organizational and pedagogical conditions for the implementation of scientific and methodological support for the training of mentors, which are necessary requirements for the quality implementation of the mentor training program and create the necessary environment for its implementation and pedagogical management;

- technological, which includes methods for organizing the process of training mentors based on the problematic and personality-active teaching concepts, which are necessary tools for the formation of psychological and pedagogical competence;

- diagnostic, criteria-based management and self-management of the process of training mentors through input control, self-control and final control of trainees; within the framework of this block the final level of psychological and pedagogical competence for each training cycle is determined and the internal qualification of the mentor is assigned [41-44].

\section{Conclusions}

The blocks presented by us (regulatory, methodological, informative, organizational, technological, diagnostic) together constitute a structural model of scientific and methodological provision of training of mentors for the system of professional education in conditions of digitalization, which contains all necessary functional information for planning, organization and implementation of internal training of mentors.

The proposed structural model of scientific and methodological support for the mentors' training is organically integrated into the internal company training system for the staff, provides the formation and expansion of psychological and pedagogical competencies of mentors, contributing to the personal development of students and the implementation of basic functions when working with interns for the purpose of training, social adaptation and professional development. The specifics of the mentor training program consists in step-by-step training and sequential mastering of «mentor, tutor», «coach», «facilitator» levels with assignment of corporate qualifications. However, the next level of mentor cannot be assigned until the previous one is received. Thus, differentiated training is carried out with building of their own development path and individual educational routes for mentors, which has become possible, including with the help of the digital navigation of the professional growth of a mentor that we are implementing as part of the experimental work.

The results of the presented study involve further study of problems of development of mentoring, internal training of employees of enterprises, development of professional competences, improvement of methods of internal training, as it is necessary to train not only certain actions and operations at the workplace, but also research, project, design activities. The relevant material is currently undergoing an experimental effectiveness test at the Autonomous Non-Profit Organization Kazan Open Talent University 2.0 in the form of a mass open online course (MOOC).

\section{Acknowledgements}

The reported study was funded by RFBR, project number 19-29-07037. 


\section{References}

1. G. V. Mukhametzyanova, N. B. Pugacheva. Methodology and experience of innovative activity in the system of vocational education: collective monograph. Kazan: Medicine. (2011).

2. N. D. Nikandrov. Prospects for the development of education in Russia. SPb: SPbGUP. (2005).

3. I. P. Smirnov. Human. Education. Profession. Personality: monograph. Moscow: Graf-Press. (2002).

4. S. A. Sedov, E. E. Merzon. Pedagogical education quality rating system development in academic physical education discipline. Teoriya i praktika fizicheskoy kultury. 8, 9-11. (2017).

5. S. A. Sedov. The determinants of the quality of higher education of teacher professional training. Education and Self Development, 13 1, 83-93. (2018).

6. O. Korableva, T. Durand, O. Kalimullina, I. Stepanova. Studying user satisfaction with the MOOC platform interfaces using the example of Coursera and open education platforms. Paper presented at the ACM International Conference Proceeding Series, 26-30, (2019). doi:10.1145/3322134.3322139

7. S. Ziyadin, S. Suieubayeva, A. Utegenova, Digital transformation in business. Lecture Notes in Networks and Systems, 84, 408-415. (2020). doi:10.1007/978-3-030-27015-5_49

8. O. Korableva, T. Durand, O. Kalimullina, I. Stepanova, Usability testing of MOOC: Identifying user interface problems. Paper presented at the ICEIS 2019 - Proceedings of the 21st International Conference on Enterprise Information Systems, 2, 468-475, (2019).

9. S. Ziyadin, B. Ermekbaeva, G. Supugaliyeva, R. Doszhan. Transformation of basic indicators of socio-economic processes in the digital economy. Paper presented at the Proceedings of the 31st International Business Information Management Association Conference, IBIMA 2018: Innovation Management and Education Excellence through Vision 2020, 2009-2017, (2018).

10. R. I. Sharafutdinov, A. G. Polyakova, V. O. Gerasimov, R. N. Shpakova, M. V. Mikhailova, Inclusive growth: A dataset on key and institutional foundations for inclusive development of russian regions. Data in Brief, 23. (2019). doi:10.1016/j.dib.2019.103864

11. V. Kolmakov, A. Polyakova. Regional free cash flow dataset: An approach to regional performance evaluation. Data in Brief, 25. (2019). doi:10.1016/j.dib.2019.104175

12. A. G. Polyakova, A. V. Pavlyuk, G. V. Meshkova. Investment appeal of a region and its impact on investment inflows. Entrepreneurship and Sustainability Issues, 7 2, 1089-1097. (2019). doi:10.9770/jesi.2019.7.2(21)

13. V. Kolmakov, A. Polyakova, S. Polyakov. A valuation approach to the russian liberal establishment consolidation. Administratie Si Management Public, 2019 32, 93-107. (2019). doi:10.24818/amp/2019.32-07

14. L. L. Ivanova. Mentoring in the state civil service: institutional aspect. State and municipal administration. Scientific notes SSGA, 4, 130-138. (2012).

15. A. R. Masalimova. The content and technology of corporate training of mentors: pedagogical component: teaching aid. Kazan: "KFU Publishing House". (2015).

16. A. S. Batyshev. The pedagogical system of mentoring in the labor collective. Moscow: Higher school. (1985).

17. N. M. Berdyklycheva. Mentoring a factor of increasing labor and social activity of working youth: Diss. ... Ph.D. Philos. Moscow. (1978).

18. L.V. Lebedeva. Mentoring as an individual form of moral education: dis ... cand. Philos. sciences. Tyumen. (1985).

19. A.A. Sidorov. Mentoring as a form of social experience transfer to the young shift of the working class in the conditions of developed socialism: author. dis ... cand. Philos. sciences. Krasnoyarsk. (1979).

20. V.A. Miroshnichenko. The mentoring pedagogy: conversations about the education of a young worker. Moscow: Profizdat. (1979).

21. I. G. Stoyar. Pedagogical issues of mentoring in the production team. Moscow: Knowledge. (1985).

22. P. F. Silenok. Evaluation activity of a mentor as a form of pedagogical management of the production adaptation of a young worker: dis ... cand. psychol. sciences. (1986).

23. I. S. Gichan. The psychological analysis of mentoring and its role in the formation of school graduates: Diss. ... Ph.D. Kiev. (1977). 
24. N. S. Smolnikova. Mentoring and moral education of youth. Political Agitation, 6, 1-8. (1980).

25. S. I. Kramarenko, I. G. Stolyar, V. S. Yazykova. Mentor's workbook: practical guide. Moscow: Profizdat. (1981).

26. S. G. Antipin. The tradition of mentoring in the history of national education: author. diss. ... Ph.D. Nizhny Novgorod. (2011).

27. I. V. Kruglova. Mentoring as a condition for the professional development of a young teacher: dis. ... Ph.D. Moscow. (2007).

28. A. N. Plotnikov. The formation of professional and pedagogical competence of a master mentor in terms of coursework: Diss. ... cand. ped sciences. Volgograd. (2006).

29. E.A. Chernikova. Mentoring as a means of supporting the professional and personal development of a social service specialist: Diss. ... Ph.D. Volgograd. (2013).

30. D.A. Krasilo. Orienting image of a mentor in the process of real self-determination: Period of entry into adulthood: dis. ... cand. psychol. sciences. Moscow. (2005).

31. E. V. Charina. Relations in the system of "mentor-young specialist" in the process of professionalization: Diss. ... Ph.D. Moscow. (2004).

32. O.A. Bogachev. Intrafirm professional training of employees in a modern enterprise: Diss. ... Ph.D. Moscow. (2011).

33. S. F. Brodsky. The introduction of new technological teaching aids and techniques in the educational process of training workers. Oil industry, 9, 143. (2006).

34. V. V. Konstantinova. Technique for optimizing the structure and content of continuing professional education at the intra-company level: Diss. ... cand. ped sciences. Voronezh. (2005).

35. V. I. Petlin. Organizational and pedagogical conditions for optimizing in-house training, retraining and advanced training of personnel in nuclear hazardous industries: based on materials of the Siberian Chemical Combine: diss. ... Ph.D. / IN AND. Petlin. Moscow. (2007).

36. H. G. Bauer. Lern (prozess) begleitung in der Ausbildung, W. Bertelsmann Verlag, Bielefeld. (2010).

37. M.J. Bock. Effizientes Personalmanagement in der Praxis, WEKA-Media, Kissing. (2008).

38. J. Homburg, Mitbestimmung und Mitwirkung beim Arbeitsverhaltnis, Bund-Verlag, Frankfurt a. (2008).

39. G. Nidermair, Betriebliche Ausbilding, Weiterbilding und Personalentwicklung, Trauner, Linz. (2009).

40. A. N. Dakhin. Pedagogical modeling: monograph. Novosibirsk: Publishing house of NIPKiPRO. (2005).

41. A. A. Listvin, The dual system of vocational training: conditions of use in Russia. Bulletin of the Cherepovets State University, 3, 118-122. (2015).

42. Order of the Government of the Russian Federation of July 9, 2014 No. 1250-r (2014). "The plan of measures to ensure increased productivity, creation and modernization of highperformance jobs". Retrieved from: http://www.garant.ru/products/ipo/prime/doc/70594184/

43. The order of the Government of the Russian Federation of March 3, 2015 No. 349-r (2015). "A set of measures aimed at improving the system of secondary vocational education, for 2015 - 2020”. Retrieved from: http://static.government.ru/media/files/cWukCnDBv5U.pdf

44. Order of the Government of the Russian Federation dated March 5, 2015 No. 366-r (2015). "Plan of measures aimed at popularizing workers and engineering professions". Retrieved from: http:/www.garant.ru/products/ipo/prime/doc/70785344/ 